\title{
Get writing!
}

\section{Phil Wiffen}

All academic journals rely on a steady stream of good quality articles in order to survive. This journal is no different and its value to readers entirely depends on the content being relevant and stimulating. My aim is that there will be something of interest to all readers in every edition. This means a balance between the academic and the practical and high-tech science and clinical wisdom.

I am often struck by two observations when it comes to hospital pharmacists: the high quality of much of the research and project work on the one hand and a seeming reluctance to publish their findings on the other. Such attitudes are rarely found among the medical staff who frequently encouraged me as a junior to

Correspondence to Phil Wiffen, Pain Research Unit, Churchill Hospital, Old Road, Oxford OX3 7LE, UK; phil.wiffen@ndcn.ox.ac.uk publish findings, often offering to help. That got me started.

Many start with a poster which is their passport to attend a conference; maybe it is now time to expand that piece of work into a full article. While the journal has word limits which can seem intimidating at times, even short papers can be valuable and I can find ways to get these into print.

There are real benefits to publishing your work: it will help your career and $\mathrm{CV}$, you will become known for your work especially if you find an interesting niche area to investigate, and you will be a greater asset to your colleagues.

In the light of this, I want to start an initiative aimed at first-time authors who want to start publishing. There will be space in this journal for those who feel that they have a suitable topic but have never published in a peer review journal before. I am willing to give support in the preparation of such papers with the aim of bringing them to a suitable standard for publication.

If you would like to submit a paper as a first time author please indicate this on the original document so it can be processed differently.

Of course those of you who are not novices are also welcome to submit papers or act as a coauthor with one of your team members

So get writing!

Competing interests None.

Provenance and peer review Commissioned; internally peer reviewed.

To cite Wiffen P. Eur J Hosp Pharm 2013;20:2.

Eur J Hosp Pharm 2013;20:2.

doi:10.1136/ejhpharm-2012-000266 